\title{
Sponge-Associated Actinobacteria: Morphological Character and Antibacterial Activity against Pathogenic Bacteria
}

\section{Aktinobakteri yang Berasosiasi dengan Spons: Karakter Morfologi dan Aktivitas Inhibisi terhadap Bakteri Patogen}

\author{
SASMIATI FARACH DITA ${ }^{1}$, SRI BUDIARTI ${ }^{2}$, YULIN LESTARI ${ }^{2,3^{*}}$ \\ ${ }^{1}$ Graduate School of Bogor Agricultural University, Dramaga, Bogor, Indonesia \\ ${ }^{2}$ Departemen Biologi, Fakultas Matemetika dan Ilmu Pengetahuan Alam, Institut Pertanian Bogor, Bogor, Indonesia \\ ${ }^{3}$ Tropical Biopharmaca Research Center, Bogor Agricultural University, Campus IPB Taman Kencana, Bogor, \\ Indonesia
}

Diterima 30 Juli 2017 /Disetujui 26 Oktober 2017

\begin{abstract}
Sponge-associated actinobacteria may diverse and have potency to produce bioactive compounds. Diversity and antimicrobial activity of indigenous sponge-asccociated actinobacteria isolated from marine ecosystem in Indonesia have not much been explored. This work aimed to assess morphological and antibacterial activity of sponge-asccociated actinobacteria. The morphological characteristics were examined based on their color of aerial and substrate mycelia, and pigmentation, while antibacterial activities were assayed using antagonist technique. Selected actinobacterial isolate was identified using 16S rRNA gene. Various sponge-associated actinobacteria were successfully isolated from Hyrtios sp., Callyspongia sp., and Neofibularia sp. sponges. A total of 62 actinobacterial isolates were obtained, and each isolates showed variety of morphological characters, which could be seen in aerial mass color, substrat mass color, and pigmentation. Actinobacterial isolates were tested against human pathogenic bacteria, i.e. Staphylococcus aureus and Methicilline Resistant $S$. aureus, representing Gram-positive, and Escherichia coli EPEC K1-1 and Shigella dysenteriae, representing Gram-negative. Most of actinobacterial isolates had antimicrobial activities at least against one of pathogenic bacteria. High activity was shown by NOHa.2, isolated from Neofibularia, and HRHa.5 isolated from Hyrtios. The NOHa.2 showed the highest antimicrobial activity against $S$. dysenteriae, meanwhile, HRHa.5 showed antimicrobial activity against 3 of 4 tested bacterial pathogens. These data showed diversity of sponge-asccociated actinobacteria from marine ecosystem in Indonesia, and several of them have potency as source of antibacterial compounds.
\end{abstract}

Key words: Actinobacteria, antibacterial activity, morphological colony, 16S rRNA gene, sponge

\section{INTRODUCTION}

Actinobacteria is a group of filamentous, Gram-positive bacteria which are well known to produce secondary metabolites, that can function as antifungal, antibacterial, antitumor, anticancer, antiviral, herbicides, antidiabetic, anthelmintic as well as antiprotozoal (Zheng et al. 2000; Solanki et al. 2008; Basha et al. 2009; Sunaryanto et al. 2010). Actinobacteria can be found in both terrestrial and aquatic environments. Aquatic or marine actinobacteria have also known to produce secondary metabolites which can be developed as microbial bioactive compound producer for health purposes.

Sponges are an invertebrate belongs to phylum Porifera, which is an important component of benthic communities in aquatic environments.

*Penulis korespondensi:

E-mail: yulinlestari@gmail.com
More than 6,000 species of sponges inhabit various ecosystems of sea water and fresh water, and found in tropics, subtropics and polar areas. These days, sponge has been the focus of much scientific study, for its associations with various microbes (Taylor et al. 2007). Sponge are also known as one of marine animals that have a great potential to generate new bioactive compounds with different efficacy. A total of 200 new bioactive compounds have been isolated from sponges (Abdelmohsen et al. 2010). More than 190 compounds with broad biological activities were isolated in Haliclona. These compounds include antifouling, antimicrobial, antifungal, antimalarial and cytotoxic activity (Kennedy et al. 2008).

Sponge is one of marine animals that can be associated with actinobacteria. More than 30 genus of sponges are known to associate with actinobacteria (Xi et al. 2012). Sponge-associated actinobacteria is suspected to be the dominant producer of bioactive compounds. Several genera of actinobacteria which known to associate with sponge were Mycobacterium, 
Micrococcus, Micromonospora, Microbacterium, Brevibacterium, Kocuria, Corynebacterium, Rhodococcus, Brachybacterium, Rubrobacter, Streptomyces, Dietzia, Salinispora, Actinokineospora, Gordonia, Arthrobacter, Nocardiopsis, Rothia (Abdelmohsen et al. 2010). Actinobacteria which inhibit aquatic environment allegedly produces different secondary metabolites compared with actinobacteria in terrestrial environment. A total of 4 new polyketide compounds i.e. Salinipirones A and B; and Pacificanones A and B were found in Salinispora pacifica (Oh et al. 2008).

Bacterial infectious diseases is one of the leading causes of death which are prevalent in tropical countries like Indonesia with a high number of patients. The emergence of this infectious disease allegedly caused by socio-economic factors, such as environment and ecological factors. Bacterial pathogens that cause human infections, for example are Escherichia coli, Shigella dysenteriae, Staphylococcus aureus, and Meticillint resistant $S$. aureus. In Indonesia, one of bacterial infectious diseases that often attack people is diarrhea. In 2014, more than 8 million cases of diarrhea were reported (Kementerian Kesehatan, 2014).

Indonesia is an archipelago country which is rich in diversity of marine biota, including variety of sponges. However, there are little information or reported data about sponge-associated actinobacteria and their potency. Based on these phenomenon, the research of potential sponge-associated actinobacteria in controlling human pathogenic bacteria is an important strategy.

\section{MATERIALS AND METHODS}

Materials. Materials used were sponge samples collected by SCUBA diving in shallow waters at a depth of 4 to 8 meters in Bira Island $\left(5^{\circ} 23^{\prime}-5^{\circ} 40^{\prime}\right.$ $\mathrm{S}, 106^{\circ} 25^{\prime} 106^{\circ} 37^{\prime} \mathrm{E}$ ) which is an island in Taman Nasional Kepulauan Seribu (52 24 ' $5^{\circ} 45^{\prime}$ S, $106^{\circ}$ $\left.25^{\prime}-106^{\circ} 40^{\prime} \mathrm{E}\right)$.

Isolation and Characterization of SpongeAssociated Actinobacteria. Sponge samples were cut and crushed in a sterile mortal and weighed. A total of $1 \mathrm{~g}$ sample was put into $9 \mathrm{~mL}$ of sterile sea water and homogenized. Dilution is done up to 10-3 dilution. A total of $0.1 \mathrm{~mL}$ suspension was plated on a sterile growth medium and incubated for 2-8 weeks. The growth media used were Humic acid with Vitamin (HV), HV with sea water, and sea water agar (M5-S). Actinobacteria isolates which were grown on that media, were then purified on Yeast Starch Agar (YSA). The media was supplemented with antibiotics cicloheximide $(100 \mathrm{mg} / \mathrm{mL})$, nystatin $(25 \mathrm{mg} / \mathrm{mL})$, and nalidixic acid $(25 \mathrm{mg} / \mathrm{mL})$. Morphological characterization was conducted by observing aerial mass color, substrate mass color, elevation, and pigmentation on the media (Dharmaraj et al. 2010).

Antagonistic Test of Actinobacteria against Pathogenic Bacteria. Pathogenic bacteria used in this study were Shygella dysenteriae, Escherichia coli EPEC K1-1, Staphylococcus aureus and Meticilline Resistant $S$. aureus (MRSA). The MRSA and $S$. dysenteria were obtained from Faculty of Medical Microbiology, University of Indonesia. The MRSA have resistancy to methicillin antibiotic. E. coli EPEC K1-1 was obtained from Microbiology Laboratory of Bogor Agricultural University. E. coli EPEC K1-1 has a resistance to ampicillin antibiotics.

Pure actinobacterial isolates were obtained after around 7-14 days grown on YSA as the purification media. Actinobacterial isolates were taken with a cork borer and placed on media Nutrient Agar (NA) which had previously been inoculated with the testing bacteria $\left(10^{6} \mathrm{cfu} / \mathrm{mL}\right)$. The plate was then incubated at $37^{\circ} \mathrm{C}$ for $18-24$ hours. Actinobacteria with the most potential was then used for further testing (Kitouni et al. 2005).

Identification of Actinobacteria based on 16S rRNA Gene. DNA was isolated using a DNA extraction kit (Geneaid). The DNA obtained was then amplified using PCR. Primers used were 20F (5'-GATTTTGATCCTGGCTCAG - 3') and 1500R (5' - GTTACCTTGTTACGACTT - 3') (Weisburg et al. 1991). PCR steps were pre denaturation for 5 min at $94^{\circ} \mathrm{C}$, denaturation for 44 seconds at $94^{\circ} \mathrm{C}$, annealing for 1 minute at $54^{\circ} \mathrm{C}$, elongation for 90 seconds at $72^{\circ} \mathrm{C}$, post-elongation for 7 minutes at $72^{\circ} \mathrm{C}$ and cooling for 15 minutes at $4^{\circ} \mathrm{C}$. This process was performed with total of 30 cycles (Zhang et al. 2013).

Visualization of the 16S rRNA gene from PCR were seen in $1 \%$ agarose gel electrophoresis in TAE buffer (Tris Acetic EDTA) 1x. Gel electrophoresis then placed on a UV illuminator to see the DNA band (visualization). PCR products were sequenced using a sequencing services company. Analysis of the sequence data was performed by doing BLAST of nucleotide sequences analysis, based on the available data at the GenBank, NCBI http://www.ncbi.nlm-nih. gov/. Furthermore, the similarity relation could be seen by constructing phylogenetic trees based on Neighbor-Joining method, with a bootstrap value of $1000 x$.

\section{RESULT}

Morphological Diversity of Sponge-Associated Actinobacteria. A total of 62 isolates of spongeassociated actinobacteria were successfully isolated. Amongst them, there were 36 isolates from Hyrtios sp. (Table 1), 13 isolates from Callyspongia sp. (Table 2), and 13 isolates from Neofibularia sp. (Table 3) which show various morphological characteristics based on aerial and substrate mycelia, pigmentation and colony elevation. The dominant color of aerial mycelium color was cream and some isolates looked gray. Meanwhile he dominant color of substrate mycelium was light brown. The actinobacterial isolates also generally did not produce pigmentation in medium. 
Table 1. Morphological characteristics of Sponge-Associated Actinobacteria with Hyrtios sp.

\begin{tabular}{|c|c|c|c|}
\hline $\begin{array}{ll}\text { Isolates } & \begin{array}{l}\text { Aerial } \\
\text { mycelium }\end{array} \\
\end{array}$ & $\begin{array}{l}\text { Substrate } \\
\text { mycelium }\end{array}$ & Pigmentation & Elevation \\
\hline HRHa.1 & Light brown & - & Raised \\
\hline HRHa.2 & Light brown & - & Raised \\
\hline HRHa.3 & Dark brown & - & Flat \\
\hline HRHa.4 & $\begin{array}{l}\text { Brownish } \\
\text { yellow }\end{array}$ & - & Flat \\
\hline HRHa.5 & Light brown & - & Flat \\
\hline HRHa.6 & Grey & - & Raised \\
\hline HRHa.8 & Light brown & - & Raised \\
\hline HRHa.9 & Light brown & - & Raised \\
\hline HRHa.10 & Light brown & - & Raised \\
\hline HRHa.12 & Light brown & - & Flat \\
\hline HRHa.13 & Light brown & - & Raised \\
\hline HRHa.14 & Light brown & - & Raised \\
\hline HRHa. $1 \backslash 5$ & Light brown & - & Raised \\
\hline HRHs.1 & Light brown & - & Raised \\
\hline HOHs.1 & Grey & - & Raised \\
\hline HOHs. 2 & Grey & - & Raised \\
\hline HOHs.3 & $\begin{array}{l}\text { Greyish } \\
\text { purple }\end{array}$ & - & Raised \\
\hline HOHs.4 & Dark brown & - & Raised \\
\hline HOHs.5 & Grey & - & Raised \\
\hline HOHs.6 & Grey & - & Raised \\
\hline HOHs.7 & Light brown & - & Raised \\
\hline HOHs.8 & Light brown & - & Raised \\
\hline HOHs.9 & Light brown & - & Raised \\
\hline HOHa.1 & Light brown & - & Raised \\
\hline НОНа. 2 & Light brown & - & Raised \\
\hline НОНа.3 & $\begin{array}{l}\text { Yellowish } \\
\text { brown }\end{array}$ & - & Flat \\
\hline НОНа.4 & $\begin{array}{l}\text { Yellowish } \\
\text { brown }\end{array}$ & - & Flat \\
\hline HOHa.5 & Light brown & - & Raised \\
\hline HOHа.6 & Light brown & - & Raised \\
\hline НОНа.7 & Light brown & - & Raised \\
\hline НОНа.8 & $\begin{array}{l}\text { Brwonish } \\
\text { yellow }\end{array}$ & - & Flat \\
\hline HOHa.9 & Light brown & - & Raised \\
\hline НОНа.10 & Dark brown & - & Raised \\
\hline НКНа.1 & $\begin{array}{l}\text { Pink keabu- } \\
\text { abuan }\end{array}$ & - & Flat \\
\hline НКНа.2 & Black & - & Raised \\
\hline НКНа.3 & Grey & - & Raised \\
\hline
\end{tabular}

Table 2. Morphological characteristics of Sponge-Associated Actinobacteria with Callyspongia sp.

\begin{tabular}{lllcl}
\hline Isolates & $\begin{array}{l}\text { Aerial } \\
\text { mycelium }\end{array}$ & $\begin{array}{l}\text { Substrate } \\
\text { mycelium }\end{array}$ & Pigmentation & Elevation \\
\hline CRHa.1 & Cream & Light brown & - & Rised \\
CRHa.2 & Cream & Light brown & - & Rised \\
CRHs.1 & Cream & Light brown & - & Rised \\
CRHs.2 & Cream & Dark brown & - & Flat \\
COHa.1 & Grey & Grey & - & Rised \\
COHa.2 & Cream & Light brown & - & Rised \\
COHa.3 & Cream & Light brown & - & Flat \\
COHa.4 & Cream & Light brown & - & Flat \\
COHa.5 & Black & Black & - & Rised \\
COHa.6 & Cream & Light brown & - & Rised \\
COS.1 & Cream & Light brown & - & Rised \\
COS.2 & Cream & Light brown & - & Rised \\
CKHs.1 & Grey & Black & Dark brown & Rised \\
\hline
\end{tabular}

As can be seen in Figure 1, actinobacteria isolated from those three sponges, which were originated from Bira Island, have various morphological characters. They produced abundance of aerial mycelia.
Table 3. Morphological characteristics of Sponge-Associated Actinobacteria with Neofibularia sp.

\begin{tabular}{lllcl}
\hline Isolates & $\begin{array}{l}\text { Aerial } \\
\text { mycelium }\end{array}$ & $\begin{array}{l}\text { Substrate } \\
\text { mycelium }\end{array}$ & Pigmentation & Elevation \\
\hline NOHa.1 & Grey & Grey & - & Raised \\
NOHa.2 & Cream & Dark brown & - & Flat \\
NOHa.3 & Cream & Dark brown & - & Raised \\
NOHa.4 & Cream & Dark brown & - & Raised \\
NOHa.5 & Cream & Light brown & - & Flat \\
NOHa.6 & Cream & Light brown & - & Flat \\
NOHs.1 & Cream & Dark brown & - & Raised \\
NOHs.2 & Cream & Light brown & - & Flat \\
NRHa.1 & Cream & Light brown & - & Raised \\
NRHa.2 & Cream & Dark brown & Brown & Raised \\
NRHs.1 & Cream & Light brown & - & Flat \\
NRHs.2 & Cream & Light brown & - & Raised \\
NRHs.3 & Cream & Light brown & - & Raised \\
\hline
\end{tabular}

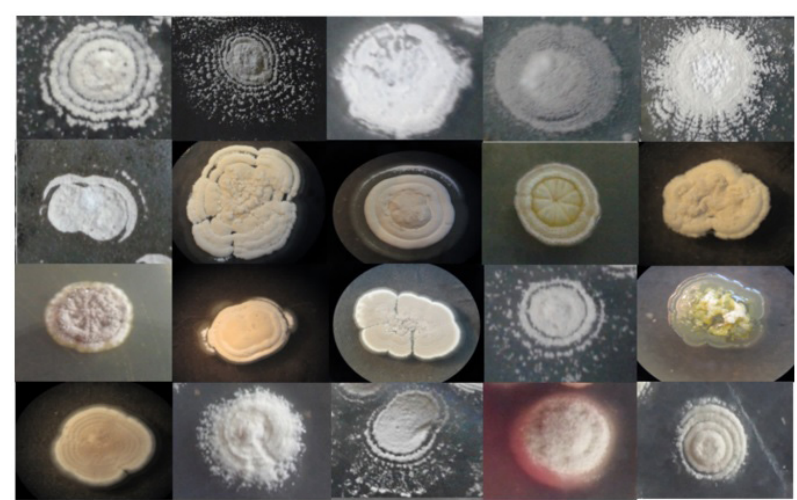

Figure 1. Sponge-associated Actinobacteria colonies grown in YSA medium for 10-14 days

The Inhibition Activity of Sponge-Associated Actinobacteria against Pathogenic Bacteria. Sponge-associated actinobacteria were generally able to inhibit the growth of $S$. dysenteriae, some isolates were able to inhibit the growth of E. coli and $S$. aureus, but no isolates were able to inhibit the growth of MRSA (Table 4, 5 and 6). Two isolates that had the highest activity were HRHa.5 from Hyrtios sp.which capable of inhibiting the growth of $E$. coli ( $5 \mathrm{~mm}), S$. dysenteriae $(5 \mathrm{~mm})$, and $S$. aureus $(1 \mathrm{~mm})$ (Table 4), and NOHa.2 from Neofibularia sp. which had the highest inhibitory activity $(14 \mathrm{~mm})$ against S. dysenteriae (Table 6). The antibacterial activity of selected actinobacterial isolates were found to be varied.

Identification of Sponge-Associated Actinobacteria Based on 16S rRNA Gene. Molecular work in identifying the HRHa.5, showed that the PCR product containing $16 \mathrm{~S}$ rRNA gene can be amplified and visualized on an agarose gel (Figure 2). Comparation of the sequence of $16 \mathrm{~S}$ rRNA gene of HRHa.5 with the available reference strains in Genbank showed similarity to Streptomyces sampsonii strain NRRL B12325 (94\%), S. champavati B-5682 strains (94\%), and S. albidoflavus DSM 40455 strains $(93 \%)$.

The phylogenetic tree analysis showed that HRHa.5 had closed relationship wth Streptomyces spp. genus (Figure 3). In this phylogenetic tree 
Table 4. The inhibition potency of Actinobacteria associated with Hyrtios sp.

\begin{tabular}{lcccc}
\hline \multirow{2}{*}{ Isolate } & \multicolumn{5}{c}{ Diameter of clear zone (mm) } \\
\cline { 2 - 5 } & S. dysenteriae & E. coli & S. aureus & MRSA \\
\hline HRHa.2 & 4 & - & - & - \\
HRHa.3 & 4 & - & - & - \\
HRHa.5 & 5 & 5 & 1 & - \\
HRHa.9 & 7 & 3 & 1 & - \\
HRHa.10 & 7 & - & - & - \\
HRHa.14 & 6 & - & - & - \\
HRHa.15 & 4 & - & - & - \\
HOHa.1 & 4 & - & - & - \\
HOHa.2 & 4 & 4 & 1 & - \\
HOHa.3 & 9 & - & 1 & - \\
HOHa.5 & 3 & - & - & - \\
HOHa.6 & 4 & - & - & - \\
HOHa.7 & 5 & - & 1 & - \\
HOHa.10 & 5 & - & - & - \\
HOHs.2 & - & 3 & - & - \\
HOHs.4 & 4 & - & 1 & - \\
HOHs.7 & 6 & 3 & 1 & - \\
HOHs.8 & 4 & - & 1 & - \\
HOHs.9 & 5 & 4 & 1 & - \\
\hline
\end{tabular}

Table 5. The Inhibition Potency of Actinobacteria Associated with Callyspongia sp.

\begin{tabular}{lcccc}
\hline Isolate & \multicolumn{5}{c}{ Diameter of clear zone (mm) } \\
\cline { 2 - 5 } & S. dysenteriae & E. coli & S. aureus & MRSA \\
\hline CRHa.1 & 5 & - & - & - \\
COHa.2 & 6 & - & - & - \\
COHa.3 & 4 & - & - & - \\
COHa.4 & 5 & - & - & - \\
COHa.9 & 9 & - & 1 & - \\
CRHs.1 & 8 & - & - & - \\
CRHs.2 & 12 & - & - & - \\
\hline
\end{tabular}

Table 6. The inhibition potency of actinobacteria associated with Neofibularia sp.

\begin{tabular}{lcccc}
\hline \multirow{2}{*}{ Isolate } & \multicolumn{5}{c}{ Diameter of clear zone $(\mathrm{mm})$} \\
\cline { 2 - 5 } & S. dysenteriae & E. coli & S. aureus & MRSA \\
\hline NRHa.1 & 6 & - & - & - \\
NOHa.2 & 14 & - & - & - \\
NOHa.3 & 11 & - & - & - \\
NOHa.4 & 8 & - & - & - \\
NOHa.5 & 5 & - & - & - \\
NOHa.6 & 3 & - & - & - \\
NRHs.1 & 10 & - & - & - \\
NRHs.2 & 9 & - & - & - \\
NRHs.3 & 12 & - & - & - \\
NOHs.1 & 12 & - & - & - \\
NOHs.2 & 9 & - & - & - \\
\hline
\end{tabular}

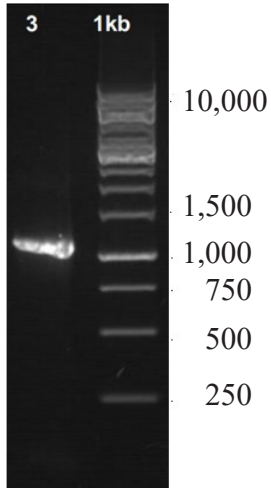

Figure 2. The electropherogram of amplified PCR product containing of $16 \mathrm{~S}$ rRNA Gene.

construction, Micromonospora sp. has diferent group position, and the outgroup used was Bacillus subtilis strain KCTC 3135, a non actinobacteria.

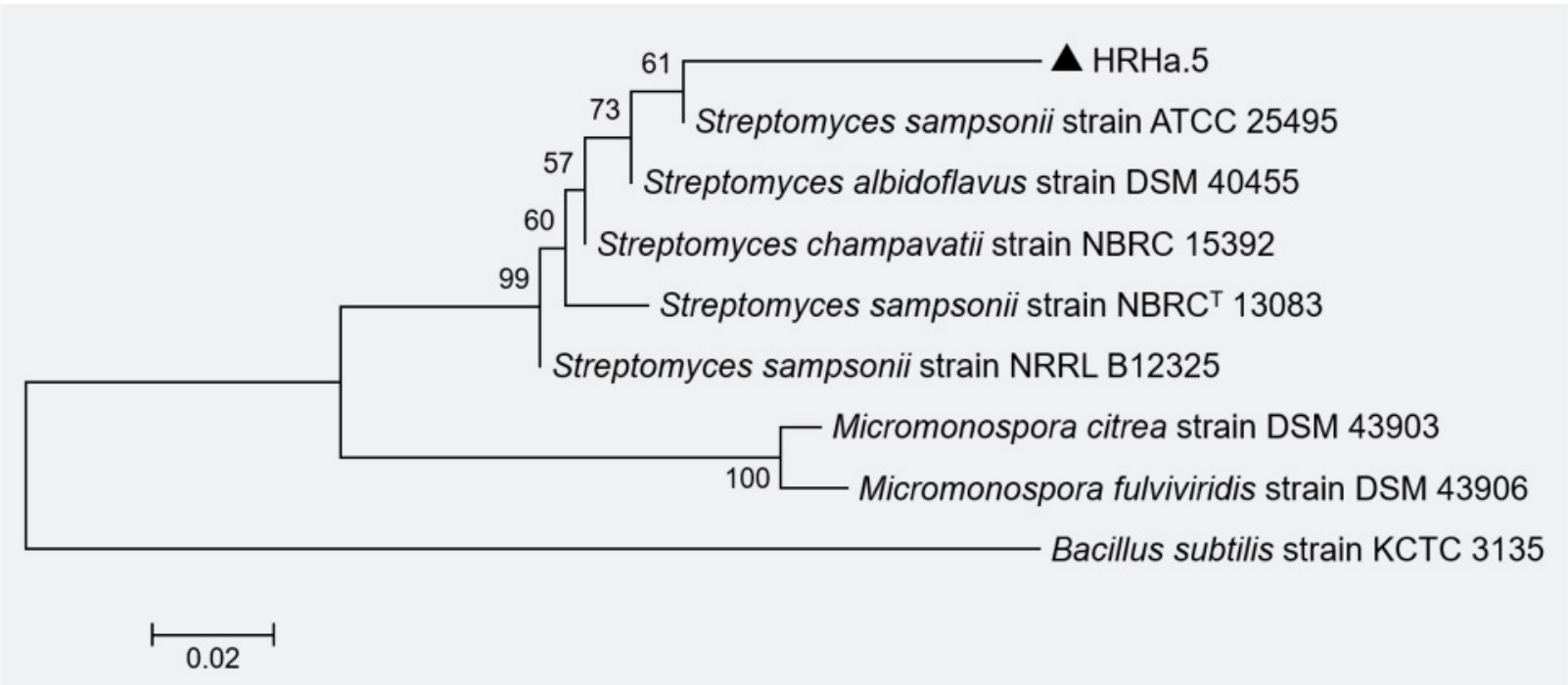

Figure 3. Phylogenetic tree of HRHa.5 based on 16S rRNA gene showing its position amongst others 


\section{DISCUSSION}

Actinobacteria which were isolated from three sponges from Bira Island showed to have various morphological characteristics, based on their aerial and substrate mycelia, pigmentation and colony elevation. Based on these morphological characteristics, sponge-associated bacteria from Bira Island were diversed. It has been reported that difference color of mycelia produced by actinobacteria can be used to indicate their diversity. It has been reported that different species may produce different physiological characters (Remnya and Vijaykumar 2008; Dharmaraj et al. 2010) which can partly be represented by various color of mycelia, pigmentation and spore chain morphology. Most of the sponge-associated actinobacteria described here are able to produce abundance of aerial mycelia, which may relate to the Streptomyces spp. characters (Shirling and Gotlieb 1966). From three sponges used as actinobacterial host, the number of isolated actinobacteria were found higher, i.e. 36 isolates from Hyrtios sp., while each of Calyspongia and Neofibularia sp. yielded 13 actinobacterial isolates, respectively. The number and diversity of sponge ascociated actinobacterial community may be influenced by kind of sponge as host that provide micro-environment suitable for for the associative actinobacteria.

Actinobacteria were mostly obtained from HV medium compared with the other two media used in this study. The HV medium is a selective media for actinobacteria, supplemented with antimicrobial substances like nystatin and nalidixic acid, which can function to controll the growth of non actinobacteria. Moreover, humic acid in the medium can be utilized as source of nutrition (organic matters) for the growth of actinobacteria. The HV medium is one of the most commonly used media in isolating actinobacteria (Zhang 2011; Jiang et al. 2013). Only a total of 2 actinobacterial isolates were obtained from M5-S medium, which might be caused by the low nutrition present in the M5-S medium.

Based on the antinobacterial data obtained, a total of 37 isolates $(59.67 \%$ ) were able to inhibit the growth of at least one of tested pathogenic bacteria. This data suporting the research results reported by Kennedy et al. 2008, and Zheng et al. 2000 where $50 \%$ and $43.6 \%$ respectively; the actinobacterial isolates obtained showed antimicrobial activity. Moreover, the results of Xi et al. (2012) also showed that $27.5 \%$ of the isolates obtained showed antimicrobial inhibitory activity. The ability to inhibit the growth of pathogenic bacteria were different in each isolates. It might be occured due to the difference of metabolite compounds produced by the isolates.

Antimicrobial inhibitory activity can be broadspectrum, narrow-spectrum, or representing activity against specific pathogens (Dharmaraj et al. 2009). The microbial activity produced by HRHa.5 may have a broad activity spectrum because it could inhibit both Gram positive and Gram negative. On the other hand, NOHa.2 showed to have a narrower spectrum or had activity against only for a particular pathogen. Antimicrobial compounds inhibit the groath of bacterial target can be based on various mechanisms, e.g. inhibiting synthesis of cell wall, membrane cell, DNA, or protein.

Hyrtios sp. has been reported to produce antimicrobial compounds and anticancer (Yousseff et al. 2013). Meanwhile, bioactive compounds produced by Callyspongia sp. may function as antimicrobes, antiprotozoa and antifouling (Dobretsov et al. 2004). For the bioprospecting of sponge-associated microbes, the sponges used were from the genus Xestospongia, Halichondria, Haliclona, and Mycale (Indraningrat et al. 2016). There was no or little data regarding the presence of sponge-associated actinobacteria from Hyrtios, Callyspongia, and Neofibularia. Therefore, these described data on morhological character which indicate diversity of sponge-associated actinobacteria from those three sponges, and the antibacterial activity against pathogenic bacteria can be considered as new information. The output of this study indicate diversity and antibacterial potency of spongeassociated actinobacteria from tropical marine environment.

Sequence identification of the 16S rRNA gene indicated that HRHa.5 has closed similarity to Streptomyces sampsonii strain NRRL B12325 with identities 1043/1115 (94\%) and gaps 45-1115, S. champavati strain B-5682 with identities 1043/1115 (94\%) and gaps 45-1115, and also with S. albidoflavus strain DSM 40455 with identities 1043/1116 (93\%) and gaps 46-1116. The NOHa. 2 had been previously identified by Simamora et al. (2016) showing that NOHa.2 had closed similarities with $S$. sampsonii strain NRRL B12325 (97\%), S. albus strain J1074 (97\%), and S. resistomycificus strain ISP 5133 (97\%). The degree of similarity less than $97.5 \%$ based on 16S rRNA gene may have novel potency as a new species (Stackebrandt and Goebel 1994). Based on the morphology and 16S rRNA gene analysis, sponge-associated actinobacteria isolated from Hyrtios sp. and Neofibularia sp. showed to have relationship with Streptomyces spp. Moreover, they can be further examined for their novelty, which based on polyphasic study, e.g. morphology, cell wall composition, physiological characters and molecular identity. The output of this work showed that marine biota like sponges from tropical marine environment associated with various kind of sponge-associated actinobacteria. 


\section{ACKNOWLEDGMENT}

Thanks to Directorate General of Higher Education for Domestic Post-Graduate Education Scholarships awarded to Sasmiati Farach Dita, and to the Department of Biology, Faculty of Mathematics and Natural Science for facilities. This research was also supported by research group activity on actinobacteria from tropical region under supervision of Yulin lestari.

\section{REFERENCES}

Abdelmohsen UR et al. 2010. Isolation, phylogenetic analiysis and anti-infective activity screening of marine spongeassociated actinobacteria. Mar Drugs 8:399-412.

Basha NS et al. 2009. Production of extracellular anti-leukaemic enzyme 1- asparaginase from marine actinobacteria by solid-state and submerged fermentation purification and characterisation. Tropical J Phar Res 8:353-360.

Kementerian Kesehatan. 2014. Farmakope Indonesia. Jakarta: Kementerian Kesehatan Republik Indonesia.

Dharmaraj S, Sumantha A. 2009. Bioactive potential of Streptomyces associated with marine sponges. World $J$ Microbiol Biotechnol 25:1971-1979.

Dharmaraj S et al. 2010. Isolation of marine Streptomyces and the evaluation of its bioactive potential. Afr J Microbiol Res $4: 240-248$.

Dobretsov S et al. 2004. Antilarval and antimicrobial activity of waterborne metabolites of the sponge Callyspongia (Euplacella) pulvinata: evidence of allelopathy. Mar Ecol Prog Ser 271:133-146.

Indraningrat AAG et al. 2016. Bioprospecting sponge-associated microbes for antimicrobial compounds. Mar Drugs 14:1-66.

Jiang Y et al. 2013. Cultivable soil actinomycete communities in some areas of western China. Acas J Biotech 1:1-13.

Kennedy J et al. 2008. Isolation and analysis of bacteria with antimicrobial activities from the marine sponge Haliclona simulans collected from Irish waters. Mar Biotechnol 11:384-396.

Kitouni et al. 2005. Isolation of actinomycetes producing bioactive substances from water, soil and tree bark samples of the north-east of Algeria. J Mycol Medical 15:45-51.

Oh DC et al. 2008. Salinipyrones and pacificanones, mixedprecursor polyketides from the marine actinomycete Salinispora pacifica. J Nat Prod 71:570-591.

Remya M, Vijaykumar R. 2008. Isolation and characterization of marine antagonistic actinobacteria from West Coast of India. Med Biol 15:13-19.

Shirling EB, Gottlieb. 1966. Methods for characterization of Streptomyces species. Int J Syst Bacteriol 16:13-340.

Simamora CJK et al. 2016. Culturable and unculturable actinobacteria associated with the sponge Neofibularia from Bira Island, Indonesia. Mal J Microbiol 12:211-220.

Solanki R et al. 2008. Bioactive compounds from marine actinobacteria. Ind J Microbiol 48:410-431.

Stackebrandt E, Goebel BM. 1994. Taxonomic note: a lace for DNA-DNA reassociation and 16S rRNA sequence analysis in the present species definition in bacteriology. Int $J$ Syst Evol Microbiol 44:846-849.

Sunaryanto R et al. 2010. Isolasi actinobacteria laut penghasil metabolit sekunder yang aktif terhadap sel kanker A549. Jurnal Pascapanen dan Bioteknologi Kelautan dan Perikanan 5:111-116.

Taylor MW et al. 2007. Sponge-associated microorganisms: evolution, ecology, and biotechnology potential. Microbiol Mol Biol Rev 71:295-347.
Xi L et al. 2012. Diversity and biosynthetic potential of culturable actinobacteria associated eight marine sponges in the China seas. Int J Mol Sci 13:5917-5932.

Youssef DTA et al. 2013. Bioactive compounds from the Red sea marine sponge Hyrtios species. Mar Drugs 11:1061-1070.

Weisburg WG et al. 1991. 16S Ribosomal DNA amplification for phylogenetic study. J Bacteriol 173:697-703.

Zhang J. 2011. Improvement of an isolation medium for actinobacteria. Mod App Sci 5:124-127.

Zhang W et al. 2013. 16S rRNA-based DGGE analysis of actinobacteria communities in fields with continuous cotton cropping in Xinjiang, China. Microbiol Ecol 66:385-393.

Zheng $\mathrm{Z}$ et al. 2000. Detection of antitumor and antimicrobial activities in marine organism associated actinobacteria isolated from the Taiwan Strait, China. FEMS Microbiol Lett 188:87-91. 